\title{
Florida Subtropical Peaches: Production Practices ${ }^{1}$
}

\author{
M. Olmstead, J. Chaparro, J. G. Williamson, R. Rouse, R. Mizell, P. Harmon, and J. Ferguson²
}

\section{Introduction}

Subtropical peach production includes many practices, such as site selection, orchard design, and disease, weed, and insect management through to harvest. Florida's subtropical climate allows growers to harvest their crops early, but it creates challenges for the long postharvest growing season. This publication covers the breadth of topics related to subtropical peach production, including a monthly timeline of recommended practices.

\section{Recommended Rootstocks}

Florida peaches, nectarines, and plums (stone fruit) are similar to other tree crops in that the desired fruit cultivar is grafted or budded onto a rootstock (Figure 1). However, unlike citrus trees, which can be grown on different rootstocks with resistance to different pests, diseases, and environmental conditions, only one rootstock, 'Flordaguard' peach rootstock, currently is recommended for Florida. This rootstock can be used for all stone fruit grown in Florida and is resistant to Meloidogyne floridensis (peach root-knot nematode) and other root-knot nematodes. Newer rootstocks 'MP-29' and 'Sharpe' show promise. Information about these rootstocks can be found at http:// edis.ifas.ufl.edu/hs366.

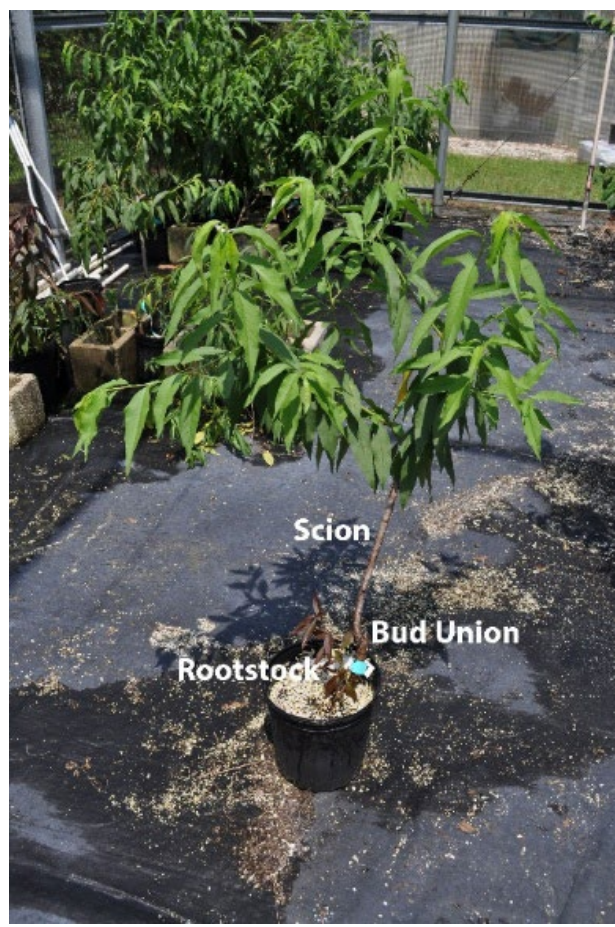

Figure 1. A budded peach tree consists of scion, bud union, and rootstock portions.

Credits: M. Olmstead

1. This document is HS1109, one of a series of the Horticultural Sciences Department, UF/IFAS Extension. Original publication date July 2007. Revised August 2013. Visit the EDIS website at http://edis.ifas.ufl.edu.

2. M. Olmstead, Extension stone fruit specialist; J. Chaparro, stone fruit breeder; J. G. Willamson, Extension fruit specialist, UF/IFAS Horticultural Sciences Department; R. Rouse, professor, Southwest Florida REC, Immokalee, FL; R. Mizell, professor, North Florida REC, Quincy, FL; P. Harmon, associate professor and Extension plant pathologist, UF/IFAS Plant Pathology Department; and J. Ferguson, professor emeritus; UF/IFAS Extension, Gainesville, FL 32611.

The use of trade names in this publication is solely for the purpose of providing specific information. UF/IFAS does not guarantee or warranty the products named, and references to them in this publication do not signify our approval to the exclusion of other products of suitable composition. All chemicals should be used in accordance with directions on the manufacturer's label. Use pesticides safely. Read and follow directions on the manufacturer's label. 
Other Florida peach rootstocks used in the past but no longer recommended are 'Nemaguard', 'Nemared', and 'Okinawa' because they are susceptible to the peach rootknot nematode.

'Flordaguard' is a red-leafed peach rootstock released by the University of Florida in 1991 (Figure 2). It is recommended for low-chill peach production in nonalkaline soils infested with root-knot nematode. Iron deficiency symptoms indicated by chlorosis are commonly found under alkaline conditions ( $\mathrm{pH}$ greater than 7.0) in calcareous soils (containing calcium and magnesium carbonates). Iron chelates may alleviate this condition.

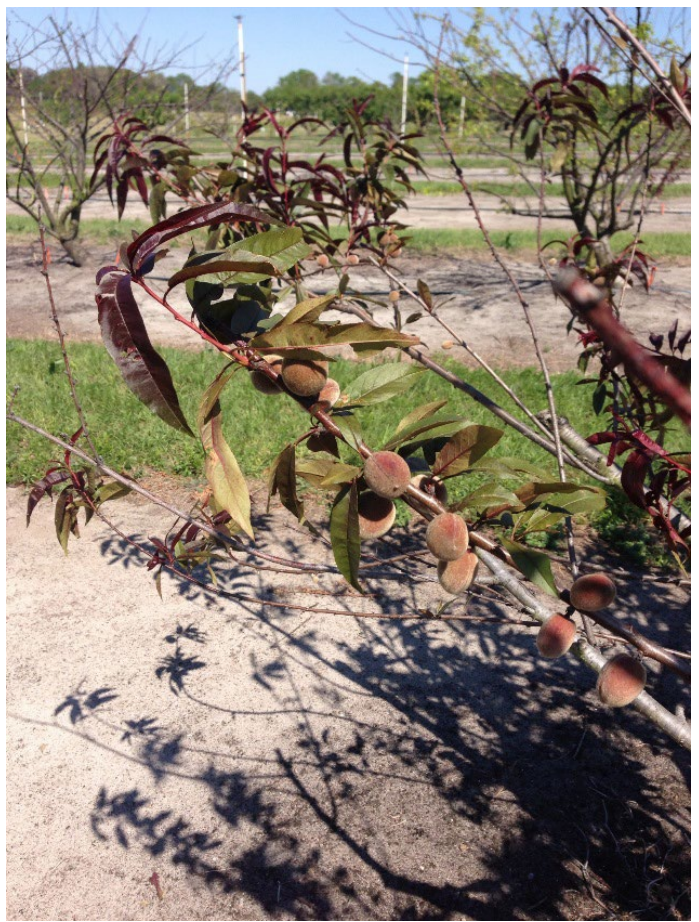

Figure 2. 'Flordaguard' fruit and red foliage.

Credits: M. Olmstead

'Flordaguard' has a chilling requirement of about 300 chill units, and flowers are self-fertile with heavy crop loads. Trees are precocious and capable of fruiting the second year, with good flower bud production. Trees produce long limbs with whippy growth that should be supported for heavy crop loads. Full bloom usually occurs February 1- 10 in Gainesville, Florida, with dull red fruit ripening in late June, about 130 days after bloom.

\section{Site Selection}

Site selection is one of the most important factors in successful peach production. In selecting a site, avoid low areas that are often subject to late spring frosts. Critical temperatures for flowers and fruit vary depending upon the stage of development, with flowers in full bloom and young fruit being the most vulnerable during low-temperature events.

Peaches and nectarines can be grown in a wide variety of soils, provided there is good internal drainage in the upper 4-6 feet of the soil profile. Avoid soils with impermeable layers, also known as "hardpans," unless an excellent system of subsoil drainage tiles is provided. Flooding damage has occurred in normally well-drained soils of medium to heavy texture during exceptionally wet summers in Florida, especially during the hurricane season.

Peach and nectarine trees can be healthy and productive on flatwood sites if there is adequate drainage, but the deep, sandy soils of the Central Florida Ridge provide good drainage and are ideal for peach and nectarine production. Peaches or nectarines grown on flatwood soils should be planted on raised beds of at least 18-24 inches to encourage drainage away from the root system. Orchard rows should be designed so that surface water runs off of the orchard beds during periods of heavy rain. Peach and nectarine trees are more sensitive to standing water than citrus and cannot withstand more than 24 hours of standing water.

Good air drainage is also important for reliable fruit production, especially when growing low-chill cultivars in areas with more than sufficient winter chilling. Lower-chill cultivars like 'UFSun' may bloom in North Florida before the risk of late spring frosts has passed. Freeze protection with overhead sprinklers may be necessary.

If possible, avoid forested areas that may provide habitat for deer, raccoon, possum, and other animals that could damage peach or nectarine trees and fruit. Although wild plum trees provide food for wildlife, they are a host for plum curculio, an insect that can infest stone fruit in North and North Central Florida. If possible, remove wild plum trees in the vicinity. Wild plums may also harbor Xylella fastidi$o s a$, the causal agent of phony peach disease (in peaches) or plum leaf scald (in plums). Mushroom root rot (Armillaria tabescens or Armillaria mellea) can also be a problem if the planting site was previously forested. Mushroom root rot is a major peach and nectarine tree disease when trees are planted where live oak or pecan trees once stood.

\section{Overhead Irrigation for Freeze Protection}

Peach and nectarine buds, flowers, and fruit can be damaged by early and late spring frosts. Flower buds that have just begun to swell can withstand temperatures to about $18^{\circ} \mathrm{F}$ (http://treefruit.yakima.wsu.edu/weatherbuds/ 
budhardiness/BudCharts/Peach\%20Bud\%20Chart\%20 EB0914.pdf). Flowers in full bloom show injury at about $27^{\circ} \mathrm{F}$. Following petal fall, young fruit generally are killed by minimum temperatures of $28^{\circ} \mathrm{F}$. However, using overhead irrigation for freeze protection can prevent such damage (Figure 3).

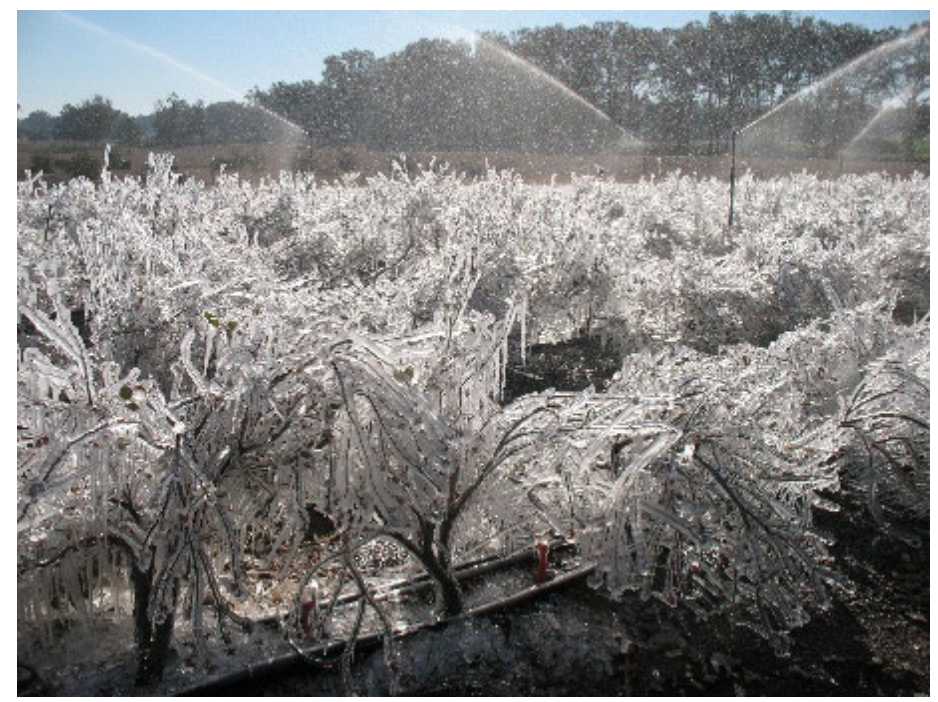

Figure 3. Overhead irrigation for freeze protection of peaches. Credits: B. Hochmuth

The underlying principle for using overhead irrigation for freeze protection is that heat lost from the trees is replaced by heat released as water turns to ice. As long as water is applied continuously at an adequate rate and is freezing, plant temperature will remain at or near $32^{\circ} \mathrm{F}$ (Figure 4). In more specific terms, when 1 pound of water freezes, 144 British Thermal Units (BTUs) of heat are released. If the irrigation rate is not high enough, evaporative cooling may lower plant temperatures and cause significantly more damage than if freeze protection was not applied. Table 1 lists

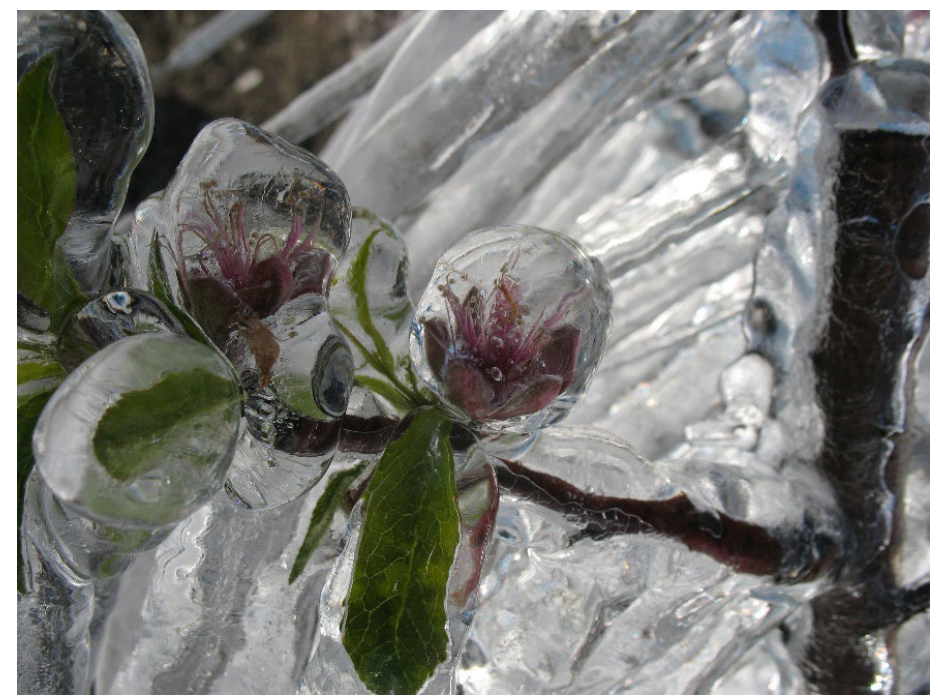

Figure 4. Proper freeze protection encases the entire branch in ice, including buds, flowers, and young fruit

Credits: J. Williamson precipitation or irrigation rates needed for freeze protection at various temperatures and wind speeds. Freeze protection with overhead irrigation is generally not recommended if wind speed is greater than $10 \mathrm{mph}$.

\section{Orchard Layout}

Peach and nectarine trees grown in Florida with an opencenter training system (see Pruning section) have traditionally been spaced at $20 \times 20$ feet, or 109 trees per acre (Table 2). Trees have also been planted at $10 \times 20$ feet ( 218 trees per acre) and $15 \times 20$ feet (145 trees per acre) with the expectation that a larger number of trees per unit area results in increased yields per acre in the orchard's early life. Certain peach and nectarine varieties with upright growth are more amenable to higher density plantings than those with spreading growth habits. The spacing between the rows must be able to accommodate all equipment necessary for managing disease, weeds, and insects, as well as other cultural practices. For lighter soils on which peach and nectarine trees are less vigorous, $15 \times 20$-foot spacing is satisfactory. All peach and nectarine cultivars currently recommended in Florida are self-fruiting and should be planted in solid blocks for easier spraying and harvesting. In contrast, plum cultivars, such as 'Gulfbeauty', 'Gulfblaze', and 'Gulfrose', require cross-pollination, and individual cultivars should not be planted in solid blocks (see Growing Plums in Florida, http://edis.ifas.ufl.edu/hs250).

\section{Planting trees}

Fumigation is recommended before planting peach or nectarine trees in sites previously used for agricultural production. This can help reduce the impact of peach root-knot nematode or diseases such as Verticillium wilt (Verticillium dahliae Kleb.). Please refer to the most recent regional disease management guide for peaches (http:// www.ent.uga.edu/peach/peachguide.pdf).

Peach and nectarine trees can be planted as bare-root plants during the dormant season, or from containers (1-2 gallon) in late January or early February as soon as the soil can be adequately worked (Figure 5). Trees that are $2 \frac{1}{1} 2-4$ feet tall establish faster than smaller trees.

In well-drained soils, plant trees slightly deeper $(\sim 1 / 2-1$ inch) than they were grown in the nursery. In flatwood soils, plant trees about the same depth as they were grown in the nursery. Both bare-root and containerized trees should be watered at planting to reduce transplant shock. Newly planted trees should receive 2-3 gallons of water for every inch of trunk diameter. Bare-root trees are dormant 


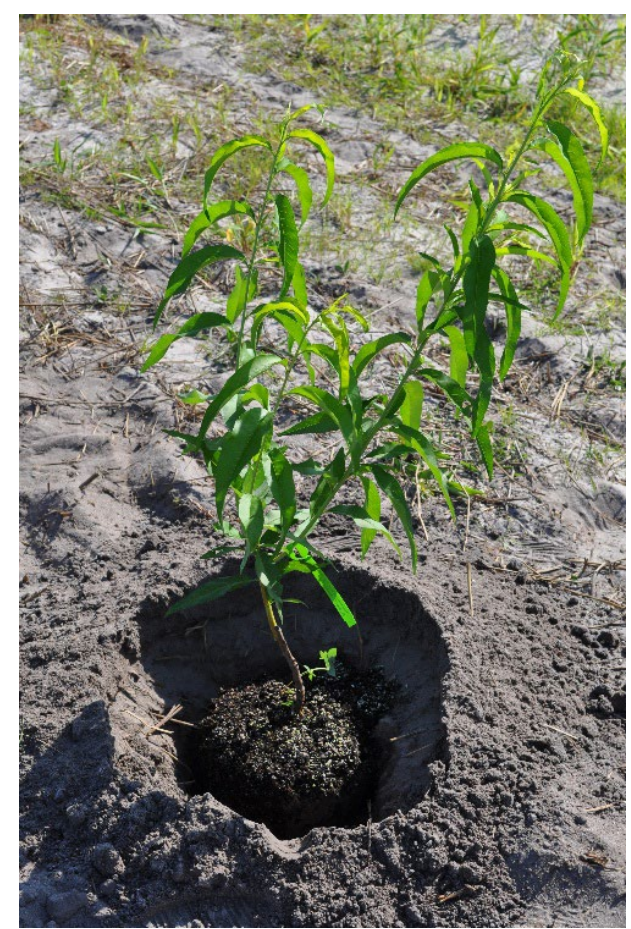

Figure 5. Containerized peach tree at planting. Notice the tree is planted slightly deeper than the top of the potted tree.

Credits: M. Olmstead

at planting, have no leaves, and usually require little if any water at planting, except on very sandy soils. However, watering and mixing the soil during the planting process for both bare-root and containerized peach trees helps prevent air pockets and ensures good root contact with the soil.

Trees planted early in the winter and kept free of weed competition require minimal watering the first season. Irrigate at least once a week during the first year, 2-3 gallons for each inch of trunk diameter. However, more frequent microsprinkler irrigation, especially with liquid fertilizers, may maximize growth during the first year. Keep a weedfree area 3-4 feet out from newly set trees the first season. Plant middle strips with oats or rye, or leave middles with a natural sod cover for protection from blowing sand and erosion. Vegetation strips made up of grass cover crop species can discourage high populations of stink bugs when compared to broadleaf weed species. Mow grass middles as needed. When trees are planted in single-row beds, swale or ditch middles should be mowed rather than disked to prevent erosion and provide a smoother surface for equipment and worker movement.

\section{Weed Control}

Best management practices for weed control in orchards address chemical and mechanical weed control measures. An herbicide strip should be applied down the tree row to maintain a weed-free area under trees, with sod planted between rows (Figure 6). The weed-free area should extend at least 5 feet on each side of the row (10 feet total). When trees are planted on 8 -foot-wide single-row beds, maintain a weed-free area 2 feet wide on each side of nonbearing trees, and maintain a sod cover on the rest of the bed to avoid soil erosion. For more information about labeled chemicals for nonbearing and bearing peaches, refer to Weed Management in Peach (http://edis.ifas.ufl.edu/wg020) or Weed Management in Nectarine (http://edis.ifas.ufl.edu/ wg019).

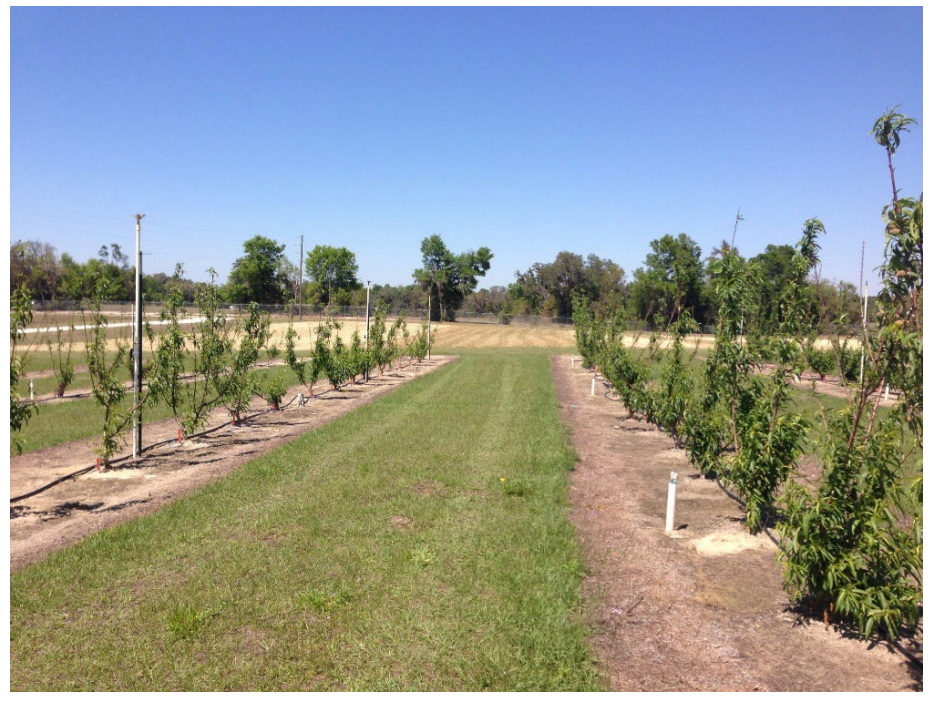

Figure 6. Weed control within the tree row.

Credits: M. Olmstead

\section{Fertilization}

Prior to planting peach or nectarine trees, a soil test should be conducted to amend nutrients. Soil samples can be sent to the UF/IFAS Extension Soil Testing Lab (http://solutionsforyourlife.ufl.edu/hot_topics/agriculture/soil_testing. html) either directly or in cooperation with your local county Extension agent. Apply any preplant fertilizers, sulfur, or liming materials as needed, depending upon initial soil tests, to bring the soil $\mathrm{pH}$ level between 6.0 and 6.5 . Dolomitic lime is recommended, especially on sandy soils if magnesium levels are low (Table 3). Because soil types vary, fertilizer recommendations for peaches or nectarines growing in loamy soils predominantly west of the Suwannee River are distinctly different from those growing on the sandy soils of peninsular Florida. It is suggested that mixed fertilizers for the western (heavier soils) area include 8-8-8 or similar materials. Fertilizers for the peninsular (sandy) area should approximate a 12-4-8 formulation (Table 4). However, further research is needed to refine fertilizer practices for Florida peaches and nectarines. 
All fertilizers should contain $1 \%$ or $2 \%$ zinc oxide $(\mathrm{ZnO})$ equivalent when used on young trees. Zinc may be supplied in the regular fertilizer program. If needed, zinc sulfate sprays (25-36 pounds in 100 gallons of water) can also be used to defoliate trees in mid to late November to induce dormancy, incidentally add zinc to the soil, and aid in bark absorption. Zinc sulfate sprays for defoliation should be applied at a semi-concentrated, moderate volume to fully wet the leaves (e.g., 100-300 gallons per acre).

Sandy soils are sometimes low in minor elements other than zinc. Boron, at rates of 5 pounds $\mathrm{B}_{2} \mathrm{O}_{3}$ per acre, and occasionally manganese, in sprays containing 0.75 pounds metallic manganese per 100 gallons, have been needed to correct symptoms. In general, use a balanced fertilizer with micronutrients.

Heavier soils in the Florida Panhandle retain more nutrients than the less fertile, sandy soils of Central Florida. However, there is little research with which to interpret soil analyses and develop base recommendations for peaches and nectarines in Florida.

Leaf analysis is recommended as a guide for fertilization. Samples should be taken from midshoot areas of average terminals April through August. Table 5 suggests leaf nutrient levels based on limited experience.

\section{Irrigation}

Bearing trees must be irrigated to increase fruit size and yield and support tree growth. Florida peaches and nectarines ripen in late April and May when rainfall is usually low. Mature trees need at least 1 acre inch of water $(27,154$ gallons per acre) per week-from soil storage, rainfall, or irrigation-for maximum fruit growth, depending upon soil type. Irrigation should be done before moisture stress becomes apparent. Suggested irrigation rates are 1-2 inches every 10 days and more frequently in sandy soils, especially during the dry season. In sandy soils with low waterholding capacity, short irrigations during the morning and evening are recommended, rather than one long irrigation. Following fruit harvest, irrigation rates should match daily evapotranspiration rates. For more information, see the evapotranspiration rate for specific locations on the Florida Automated Weather Network, http://fawn.ifas.ufl.edu/tools/ et/.

\section{Pruning}

Pruning is necessary to form a well-shaped, strong tree and to maximize production of high-quality fruit. The predominant system in Florida is an open-center or open-vase system with three to five scaffolds covering $360^{\circ}$ (Figure 7). When planted, trees can be cut back to a single stem 15-20 inches high. This encourages lateral branching and various shoots from which scaffold branches can be selected. If lateral branches have formed on the nursery tree, cut the laterals off nearly flush with the stem if they are within 12 inches of the soil line. If lateral branches have already formed in an appropriate location for scaffold development (see below), they can be left on and pruned back to 1-2 inches long or longer if desired. For trees planted in the autumn, select three or four evenly spaced, vigorous, wide-angled shoots to be the major scaffold branches between 10 and 20 inches from the soil surface. Remove or cut back other shoots and remove all low-growing suckers, including those from the rootstock when growth begins in February and March.

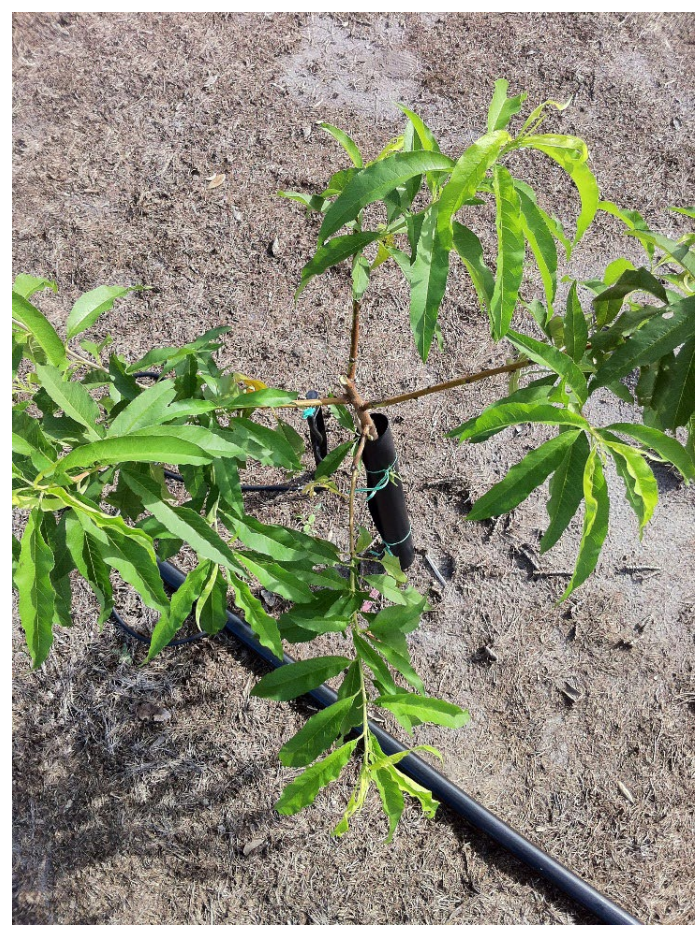

Figure 7. One-year-old peach tree pruned to four main scaffolds. Credits: M. Olmstead

In the first winter after planting, cut back the main scaffold branches that developed during the previous growing season by approximately a third to allow lateral branches growing on the scaffold to spread. Water sprouts and limbs that are too low should also be removed. The height of limbs selected to be scaffolds affects the eventual height of the canopy from ground level; orchards in Florida are maintained at a height of about 8 feet. The tree canopy should be low enough to facilitate fruit harvest from ground level but high enough for management practices, such as weed management, fertilization, and irrigation 
line maintenance. Continue this training procedure for the second and third winters. Bearing trees can be pruned in late December to early January. As the trees grow larger (3+ years), the main objectives of winter pruning are to remove overcrowded branches and water sprouts, and to head back terminal growth to prevent excessive tree vigor (Figure 8). This keeps the center of the tree open to allow sunlight to reach all parts of the tree. Take care to keep three to four short shoots in the center of the tree. This provides some shade to prevent the upper surfaces of scaffold limbs from getting sunburned and cracked. In order to reduce excess fruit load, fruiting laterals need to be thinned and renewed depending on vigor, flower bud set, and cultivar habits. To promote bud development lower on the tree and control tree height, top vigorous shoots and remove vigorous sprouts from the center of the tree in summer after harvest.

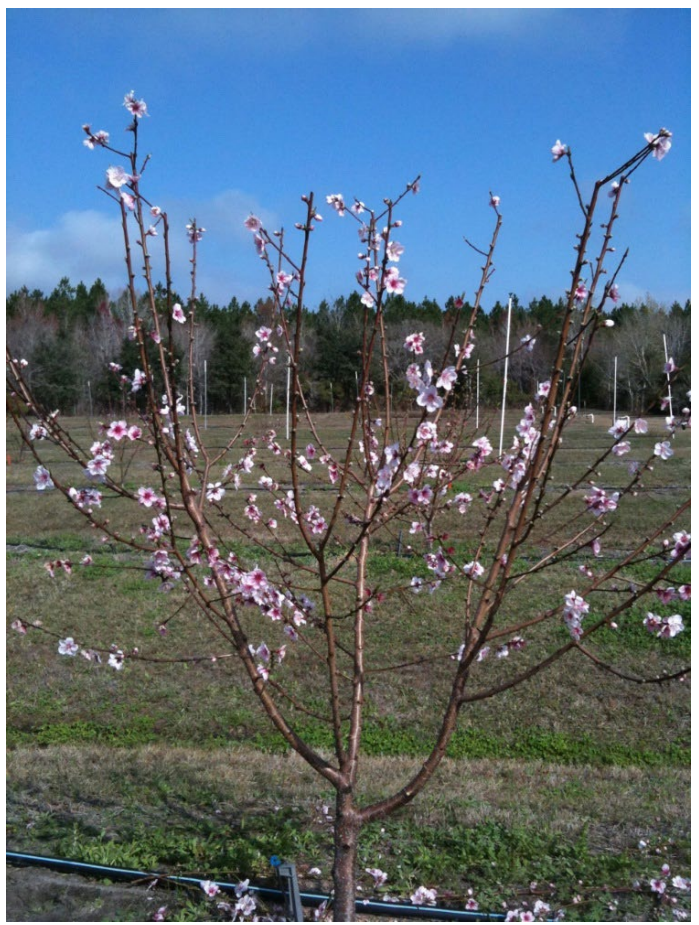

Figure 8. Two-year-old tree with branches distributed around the circumference of the tree.

Credits: J. Breman

Pruning is a time-consuming, costly operation. Along with fruit thinning, it is one of the major production costs. Studies from other production areas have shown that 18-23 hours of labor per acre are required for pruning, and 21-35 hours are required for thinning heavy crops. Other studies have found that mechanical hedging, followed by some hand-detailed pruning, can cut pruning time in half.

\section{Thinning}

Peach and nectarine trees usually set more fruit than can be grown to marketable size and quality, even when pruning is used to control fruit load. To improve fruit size and early ripening, thinning should be done as early as possible.

Thinning fruit by hand is time and labor intensive, but can produce the best results. At present, no recommendations are available on the use of chemical sprays for thinning peach and nectarine fruit under Florida conditions. Fruit should be thinned before pit hardening, leaving about one fruit on average every $6-10$ inches along the branch. Pit hardening can be determined by slicing young fruit in half to determine if the pit has begun to harden, usually before they are about the size of a marble or nickel. Thinning reduces total yield, but profit depends on the price as it relates to fruit size. Determine the extent of thinning based on market demands and cultivar response to thinning. In many cases, $60 \%-70 \%$ of the fruit must be removed to achieve good fruit size and quality. Some growers thin blossoms during bloom when conditions favor heavy fruit set. However, blossom thinning is not recommended because frost events may reduce the crop beyond economic viability.

\section{Harvesting and Marketing}

Peaches and nectarines are harvested when mature and often after ripening initiation (i.e., "tree ripe"), but when still firm enough to ship well. Ground color change from green to yellow in addition to blush amount are used to judge harvest maturity. Peaches and nectarines for local markets can be picked tree ripe, or at least more mature than those to be shipped long distances. A rapid increase in quality and size occurs during the ripening stage, and judgment is necessary to obtain maximum quality while avoiding losses from over maturity or ripeness. Peaches or nectarines with nonmelting flesh maintain firmness and have a longer shelf life than those with melting flesh; thus, they can stay on the tree longer before being harvested for shipping.

Pick and handle peach and nectarine fruit carefully to prevent bruising. Peaches and nectarines do not mature uniformly, and fruit must be harvested three to four times at 2-3-day intervals in order to obtain harvestable fruit.

Fruit must be carefully graded, sized, cooled, and packed for long-distance shipment. This requires a sizeable investment in a packing house, which is not likely to prove economically feasible with less than 50-150 acres. Growers having up to 20 acres may be able to sell fruit through U-pick operations or at local markets without extensive packing. In such orchards, a succession of cultivars is essential. See Florida Peach and Nectarine Varieties (http:// edis.ifas.ufl.edu/mg374) to select cultivars with different fruit development periods to ensure successive crop maturity dates for your area. 
Another important consideration in harvesting and marketing is to plan cultivar plantings to ensure even use of harvest labor and packing facilities over as long a period as possible. New cultivars are available to provide a ripening succession in Central and South Central Florida from early April through mid-May. One or more cultivars ripening together probably should not constitute more than $50 \%$ of the total acreage, assuming a harvest period of 7-10 days for a cultivar.

\section{Peach and Nectarine Pest and Disease Management}

Pests in Florida peaches and nectarines occur throughout the season and attack both the trees and fruit. The primary pests of fruit are plum curculio (North Central and North Florida), stink bugs, and Caribbean fruit fly (Central and South Florida). Occasional fruit pests include scarab beetles, thrips, and nitidulid sap beetles. The major pests of the tree trunk and roots are the peach tree borer, which attacks the base and lower scaffold limbs of the tree; the lesser peach tree borer, which attacks scaffold branches; white peach scale; and San Jose scale. Since systematic research on pest damage to stone fruit has not been widely conducted in South Florida, damage caused by other pests specific to that area may increase as plantings expand, requiring additional management.

As increasing numbers of orchards are planted in former citrus groves, root weevils, such as blue green weevils (Pachnaeus litus and Pachnaeus opalus) and diaprepes (Diaprepes abbreviates) root weevil, have been found on peach root systems. These insects can be responsible for tree decline and death in peaches as well as in citrus crops. The most damaging stage of both types of root weevils is the larval stage, at which time they can weave their way through the root system, creating extensive "galleries" or mazes of damage. For more information, images, and management options for root weevils, see Field Diagnosis of Citrus Root Weevil Damage (http://edis.ifas.ufl.edu/hs260) or Diaprepes Root Weevil (http://edis.ifas.ufl.edu/in151). When applying chemical controls for insect pests, adhere to pesticide label instructions and rates for stone fruit. The label is the law. In many cases, chemicals labeled for citrus and other crops may not have stone fruit on the label and thus cannot be used for chemical pest control.

In South Florida, the Caribbean fruit fly ("caribfly") is a serious pest of peaches and nectarines (see http://edis.ifas. ufl.edu/in353 for more information). Plum curculio does not appear to be a problem in South Central Florida, but it is the most serious peach pest in Central and North Florida, where wild plums are common (see http://edis.ifas.ufl.edu/ ig075 for more information). Around Gainesville, major egg-laying periods on fruit have ranged between March 1 and April 1. Caribfly egg-laying activity appears to be timed with the shuck-split stage in wild plums (usually 15-20 days after full bloom). Sprays applied during early to mid-March are generally effective, but should be modified with seasonal differences. Egg laying is prolonged through the month of March if cool weather persists, and an additional spray may be needed depending upon the chemical used.

Sucking insects called stink bugs cause "catfacing" or "dimpling" and gumming of fruits from early season feeding. They also increase brown rot damage in mature fruit. The brown marmorated stink bug is a severe pest and has been detected in Florida, although it is not yet widespread (see http://edis.ifas.ufl.edu/in623 for more information). This stink bug can cause severe damage to the fruit surface and render affected fruit unsalable. Sprays for stink bugs may be needed prior to first leaf flush on early flowering cultivars. For current recommended chemicals and rates, please consult the Southeastern Peach, Nectarine and Plum Pest Management and Culture Guide (http://www.ent.uga. edu/peach/PeachGuide.pdf). Where cultural conditions permit, eliminating legume cover crops, such as peas, beans, crotalaria, and beggar-weed, has resulted in some population reduction.

Borers are a problem throughout Central and North Florida. Uncontrolled populations ruin trees by severely girdling the scaffolds or tree trunk at the soil line. The lesser peach tree borer attacks the tree framework at injuries or at large pruning cuts. The lesser peach tree borer lays eggs earlier in the season, has more life cycles per summer than the peach tree borer (at least two), and requires sprays as soon as possible after fruit harvest. Borers in dooryard trees can be removed by hand digging under gum spots in late summer and fall. Remove small white grubs, which are the immature stages of the borer.

White peach scale, common throughout the state, occurs throughout the year and can kill both small and large branches. It has a wide host range, and alternate host trees, such as chinaberry and mulberry, should be removed from areas within 200-300 yards of the orchard to reduce spread of white peach scale into the orchard. High numbers of white peach scale males give the trees a fuzzy, snow white appearance (see http://edis.ifas.ufl.edu/in233 for more information). 
San Jose scale is a much smaller species that can cause more severe dieback of branches in a shorter period of time than white peach scale. Infested branches appear silvery and grow poorly. San Jose scale can be controlled during dormancy by applying two applications of dormant oil prior to bud swell. Spray should be applied to wet down all limb and trunk surfaces. Hand spraying or an airblast sprayer can be used with a rate of at least 125 gallons of the final mix/acre for effective coverage. Chemicals applied to control plum curculio and stink bugs may help manage scale, or in the case of pyrethroids, make them worse. Chemical sprays for borers after harvest usually suppress scale.

\section{Diseases}

Peach scab (Cladosporium carpophylium) affects peaches and nectarines in all areas of the state, causing small brown spots with a green halo on the fruit skin (Figure 9). Chemical or organic fungicide applications are recommended from fruit set through harvest to control peach scab. However, the earliest peach and nectarine cultivars ripen before lesions are very noticeable.

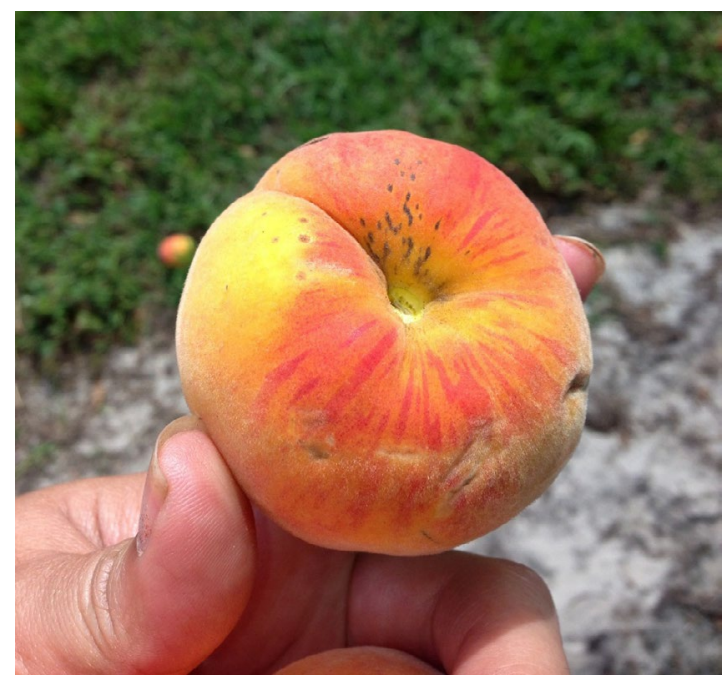

Figure 9. Peach scab on 'UFSun' fruit, showing lesions around where the pedicel was located.

Credits: M. Olmstead

Bacterial spot (Xanthomonas campestris pv. pruni) can be serious on 'Flordaprince' and 'Tropicbeauty' peaches in some years, and it is difficult to control. Growing peach and nectarine varieties with resistance to bacterial spot is the best control measure, and many of the recently released cultivars have good resistance to bacterial spot. Wellfertilized trees are less susceptible to bacterial spot than underfertilized trees.

Brown rot (Monilinia fruticola) has not been a very serious problem on early peaches in Central and South Central Florida because of the characteristically dry climate in April and May. Brown rot can be quite serious in North Florida during springs with blowing rain, and it can also be a serious problem in late-ripening cultivars that typically reach maturity after summer rains begin. The brown rot fungus can infect the flowers, fruit, and shoots of peaches. When it infects flowers, it is known as blossom blight. Brown spores often show up on fruit (Figure 10) and can result in dried and decaying fruit (mummies) on the tree. These mummies then serve as inocula to fuel disease spread throughout the orchard.

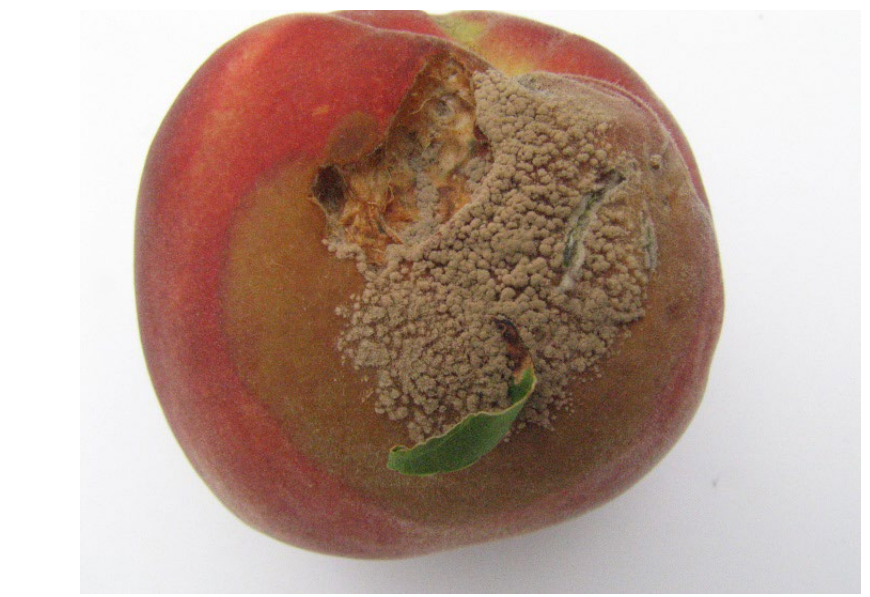

Figure 10. Brown rot on peach.

Credits: G. England

Peach leaf rust (Tranzschelia spp.) is one of the more serious diseases in Central Florida (Figure 11). Severe defoliation can occur by midsummer in some instances and undoubtedly weakens the trees. Early fall defoliation can result in off-season bloom during fall and winter, which reduces yield the following spring. In North Florida, infection usually does not appear until late summer or fall, as it does in Georgia and South Carolina, where the disease is considered to be of minor importance.

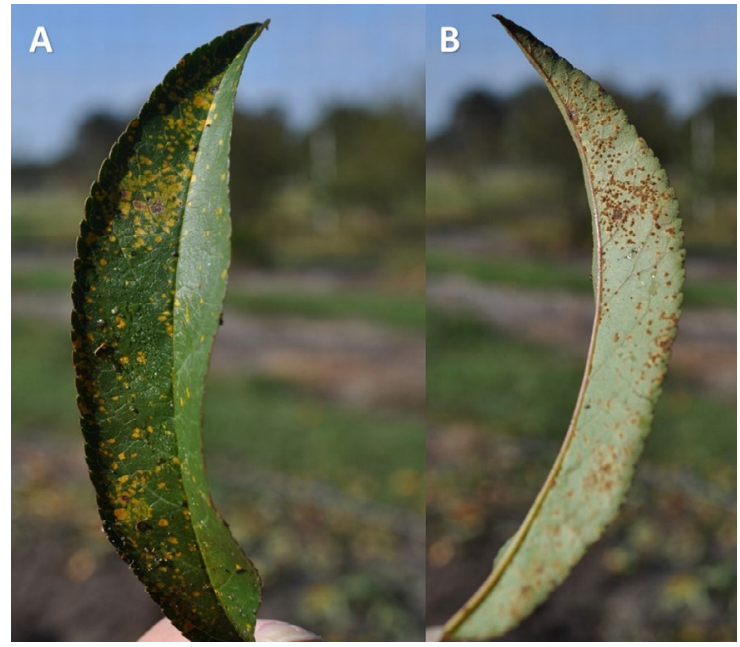

Figure 11. Peach leaf rust on the top (A) and bottom (B) of a peach leaf. Severe infections result in groups of brown spores on the underside of the leaf and can cause tree defoliation.

Credits: M. Olmstead 
Mushroom root rot (Armillaria tabescens and A. mellea) is a fungal disease often present in newly cleared areas where oak and hickory were growing. This fungus has high incidences where peaches are planted on old pecan and tung nut land. There is no practical control, other than planting on sites relatively free of decaying oak or other hardwood roots. Rootstocks with good resistance to Armillaria are being developed. A recent release, 'MP-29', is available through major peach nurseries. Symptoms of Armillaria infection include sudden wilting, usually starting about the third year in the orchard. Cutting through the bark at and just below the ground line discloses a thin, white mat of fungal growth between the bark and wood. This white growth may be visible on only one side of the tree or may completely encircle the tree (Figure 12). Fungi may also appear.

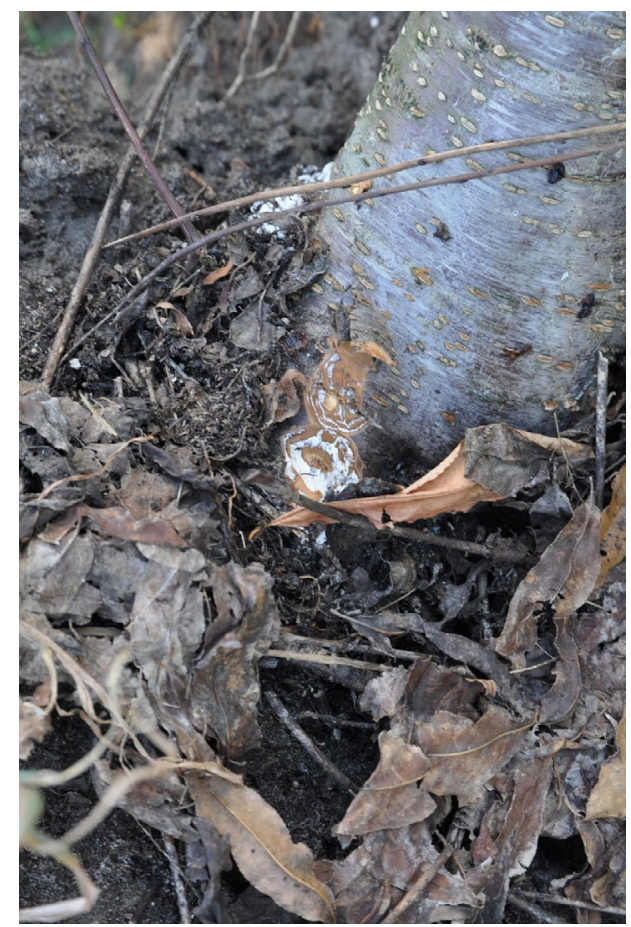

Figure 12. Mushroom root rot caused by Armillaria spp. in peaches shown with a cut in the bark near the soil line. Notice white hyphae just under the bark before cutting into the wood.

Credits: M. Olmstead

Phony peach, a systemic disease caused by a xylem-limited bacterium, Xylella fastidiosa, occurs in all established peach-growing areas in Florida. It is introduced in nursery stocks, in infected budwood, or from wild hosts. The phony peach bacterium is found in wild plum trees in Florida, but causes no observable damage to these plums. When transmitted to the peach by leafhoppers, it causes tree dwarfing, distorted small fruit, and poor fruit production. Before planting peaches, remove or kill all wild plums within a quarter mile of the orchard if possible. If peaches or nectarines are being propagated and budded onto rootstock, use T-budding rather than chip budding. Avoid using buds that contain woody material to limit transmission of the xylem-limited bacteria associated with phony peach disease.

Table 6 provides a production schedule for peaches and nectarines that can also be adapted for plums. Production practices may differ from North Central Florida, depending on pest and disease incidence and severity. 
Table 1. Precipitation rate needed for freeze protection at varying temperatures and wind speeds

\begin{tabular}{|c|c|c|c|c|c|c|}
\hline \multirow{3}{*}{$\begin{array}{c}\text { Temperature of an } \\
\text { unprotected dry leaf } \\
{ }^{\circ} \mathrm{F}\end{array}$} & \multicolumn{6}{|c|}{ Wind speed in $\mathrm{mph}$} \\
\hline & 0 to 1 & 2 to 4 & 5 to 8 & 10 to 14 & 18 to 22 & $30+$ \\
\hline & \multicolumn{6}{|c|}{ Acre-inches per hour needed for freeze protection } \\
\hline 27 & 0.10 & 0.10 & 0.10 & 0.10 & 0.20 & 0.30 \\
\hline 26 & 0.10 & 0.10 & 0.14 & 0.20 & 0.40 & 0.60 \\
\hline 24 & 0.10 & 0.16 & 0.30 & 0.40 & 0.80 & 1.6 \\
\hline 22 & 0.12 & 0.24 & 0.50 & 0.60 & 1.20 & 1.80 \\
\hline 20 & 0.16 & 0.30 & 0.60 & 0.80 & 1.6 & 2.4 \\
\hline 18 & 0.20 & 0.40 & 0.70 & 1.0 & 2.0 & 3.0 \\
\hline 15 & 0.26 & 0.50 & 0.90 & 1.3 & 2.6 & 4.0 \\
\hline 11 & 0.34 & 0.70 & 1.2 & 1.7 & 3.4 & 5.0 \\
\hline \multicolumn{7}{|c|}{$\begin{array}{l}\text { (Source: Gerber, J. F. and J. D. Martsolf. 1965. Protecting citrus from cold damage. CIR 287. Gainesville: University of Florida Institute of Food and } \\
\text { Agricultrual Sciences.) }\end{array}$} \\
\hline
\end{tabular}

Table 2. Various peach tree densities based on spacing between rows and between trees

\begin{tabular}{|c|c|c|}
\hline $\begin{array}{c}\text { Spacing between trees } \\
(\mathrm{ft} .)\end{array}$ & $\begin{array}{c}\text { Spacing between rows } \\
(\mathrm{ft} .)\end{array}$ & Trees per acre \\
\hline 10 & 20 & 218 \\
\hline 15 & 20 & 145 \\
\hline 15 & 15 & 194 \\
\hline 20 & 20 & 109 \\
\hline
\end{tabular}

Table 3. Characteristics of liming materials

\begin{tabular}{|c|c|c|c|}
\hline Source of lime & $\begin{array}{l}\text { Calcium carbonate } \\
\text { equivalent }\end{array}$ & Timing of breakdown & $\begin{array}{l}\text { Maximum recommended rate (for } \\
\text { soils below pH 5.5) }\end{array}$ \\
\hline $\begin{array}{l}\text { Agricultural limestone } \\
\left(\mathrm{CaCO}_{3}\right)\end{array}$ & $70-95$ & Slow & $1-2$ lb. per $100 \mathrm{ft}^{2}$ \\
\hline Hydrated lime $\left(\mathrm{Ca}(\mathrm{OH})_{2}\right)$ & 140 & Fast & $20 \mathrm{lb}$. per $1000 \mathrm{ft}^{2}$ \\
\hline Burned lime & 180 & Fast & $50 \mathrm{lb}$. per $1000 \mathrm{ft}^{2}$ \\
\hline $\begin{array}{l}\text { Dolomitic Lime }\left(\mathrm{CaCO}_{3}+\right. \\
\left.\mathrm{MgCO}_{3}\right)\end{array}$ & $70-95$ & Slow, provides Mg & $50 \mathrm{lb}$. per $1000 \mathrm{ft}^{2}$ \\
\hline Pelletized lime & $70-95$ & Slow & $50 \mathrm{lb}$. per $1000 \mathrm{ft}^{2}$ \\
\hline
\end{tabular}


Table 4. Current recommended fertilizer rates for Florida peaches

\begin{tabular}{|c|c|c|}
\hline \multirow[t]{2}{*}{ Application date } & \multicolumn{2}{|c|}{ Soil type } \\
\hline & $\begin{array}{c}\text { Sandy soils } \\
(12-4-8)\end{array}$ & $\begin{array}{l}\text { Loamy soils } \\
(8-8-8)\end{array}$ \\
\hline \multicolumn{3}{|c|}{ Year 1} \\
\hline \multicolumn{3}{|c|}{ Lb. mixed fertilizer } \\
\hline February & 0.12 & 0.5 \\
\hline Late May & 0.25 & \\
\hline June & & 0.5 \\
\hline July & 0.50 & \\
\hline August & & $\begin{array}{c}\text { Nitrogen options: } \\
\text { Use ammonium nitrate }(33 \% \mathrm{~N}) \text { if nitrogen is } \\
\text { leached during wet seasons }\end{array}$ \\
\hline TOTAL ANNUAL APPLICATION & $\begin{array}{c}0.87 \mathrm{lb} . / \text { tree/year or } 93.96 \mathrm{lb} . / 108 \text { trees/per acre/ } \\
\text { year or } \\
11.27 \mathrm{lb} . \mathrm{N} ; \\
3.75 \mathrm{Ib} . \mathrm{P}_{2} \mathrm{O}_{5} ; \\
7.5 \mathrm{Ib} . \mathrm{K}_{2} \mathrm{O}\end{array}$ & $\begin{array}{l}1.25 \mathrm{lb} . / \text { tree/year or } 135 \mathrm{lb} . / 108 \text { trees/acre/year or } \\
12.82 \mathrm{lb} . \mathrm{N} \\
8.64 \mathrm{lb} . \mathrm{P}_{2} \mathrm{O}_{5} \\
8.64 \mathrm{lb} . \mathrm{K}_{2} \mathrm{O}\end{array}$ \\
\hline \multicolumn{3}{|c|}{$\begin{array}{l}\text { For young trees, add in } 1 \%-2 \% \text { zinc oxide in granular fertilizer } \\
\text { Apply fertilizer in the first year in a circular area } 6-24 \text { inches from the trunk to prevent fertilizer burn to the root system }\end{array}$} \\
\hline \multicolumn{3}{|c|}{ Year 2} \\
\hline Application date & $\begin{array}{c}\text { Sandy soils } \\
\text { (central Florida) } \\
(12-4-8)\end{array}$ & $\begin{array}{l}\text { Loamy soils } \\
\text { (North and West Florida) } \\
(8-8-8)\end{array}$ \\
\hline January & $1-1.5$ & $1-1.5$ \\
\hline May & $1-1.5$ & $1-1.5$ \\
\hline TOTAL ANNUAL APPLICATION & $\begin{array}{l}\text { 216-324 lb./acre/year or } \\
\text { 25.9-38.9 lb. N }\end{array}$ & $\begin{array}{l}216-324 \mathrm{lb} . / \mathrm{acre} / \mathrm{year} \text { or } \\
17.3-25.9 \mathrm{lb} . \mathrm{N}\end{array}$ \\
\hline \multicolumn{3}{|c|}{ Year 3+ } \\
\hline January & \multicolumn{2}{|c|}{ 30-40 lb. nitrogen per acre in mixed fertilizer as above } \\
\hline May (after harvest) & \multicolumn{2}{|c|}{ 30-40 lb. nitrogen per acre in mixed fertilizer as above } \\
\hline August & \multicolumn{2}{|c|}{ 20-30 lb. nitrogen per acre during August if wet conditions } \\
\hline TOTAL ANNUAL APPLICATION & \multicolumn{2}{|c|}{ 80-110 lb. N/acre } \\
\hline
\end{tabular}


Table 5. Leaf nutrient analysis levels in peach

\begin{tabular}{|c|c|c|}
\hline & Low range & Optimum range \\
\hline & \multicolumn{2}{|c|}{ Element (\%) } \\
\hline Nitrogen(N) & Less than 2.5 & $2.75-3.5$ \\
\hline Phosphorus $(P)^{*}$ & Less than 0.10 & $0.12-0.5$ \\
\hline Potassium (K) & Less than 1.0 & $1.50-2.50$ \\
\hline \multirow[t]{2}{*}{ Calcium (Ca) } & Less than 0.80 & $1.25-2.5$ \\
\hline & \multicolumn{2}{|c|}{ Element (ppm) } \\
\hline Magnesium (Mg) & Less than 0.25 & $0.25-0.5$ \\
\hline Iron (Fe) & Less than 60 & $60-400$ \\
\hline Manganese $(\mathrm{Mn})^{* *}$ & Less than 20 & $20-150$ \\
\hline Zinc (Zn) & Less than 15 & $15-50$ \\
\hline Copper (Cu) & Less than 5 & $5-20$ \\
\hline Boron $(B)^{* * *}$ & Less than 20 & $20-45$ \\
\hline \multicolumn{3}{|c|}{$\begin{array}{l}\text { *If } \mathrm{P} \text { is high, } \mathrm{Zn} \text { may be deficient at } 18 \mathrm{ppm} \text {. } \\
\text { **Mn in excess of } 150 \mathrm{ppm} \text { is a good indication of low soil pH. } \\
{ }^{* * *} \text { Boron levels greater than } 50 \text { ppm may be toxic. }\end{array}$} \\
\hline \multicolumn{3}{|c|}{$\begin{array}{l}\text { (Source: Horton, D., P. Brannen, B. Bellinger, D. Lockwood, and D. Ritchie. 2013. Southeastern Peach, Nectarine and Plum Pest Management and } \\
\text { Culture Guide. Athens: University of Georgia. http://www.ent.uga.edu/peach/PeachGuide.pdf.) } \\
\text { (Source: LaRue, J. H., and R. S. Johnson. 1989. Peaches, Plums and Nectarines Growing and Handling for Fruit Market. UC Cooperative Extension } \\
\text { Publication 3331-1989. Davis: University of California.) }\end{array}$} \\
\hline
\end{tabular}




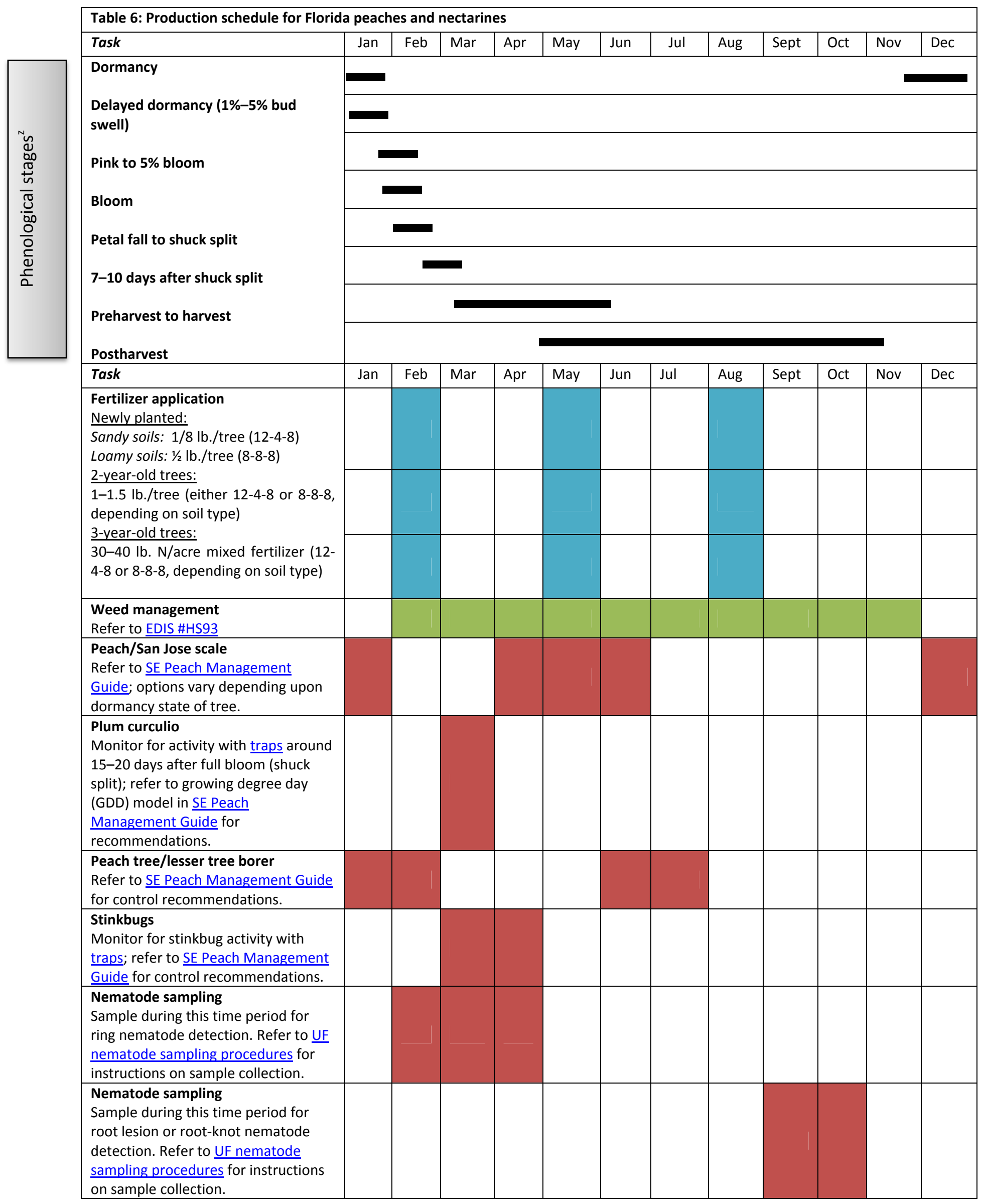




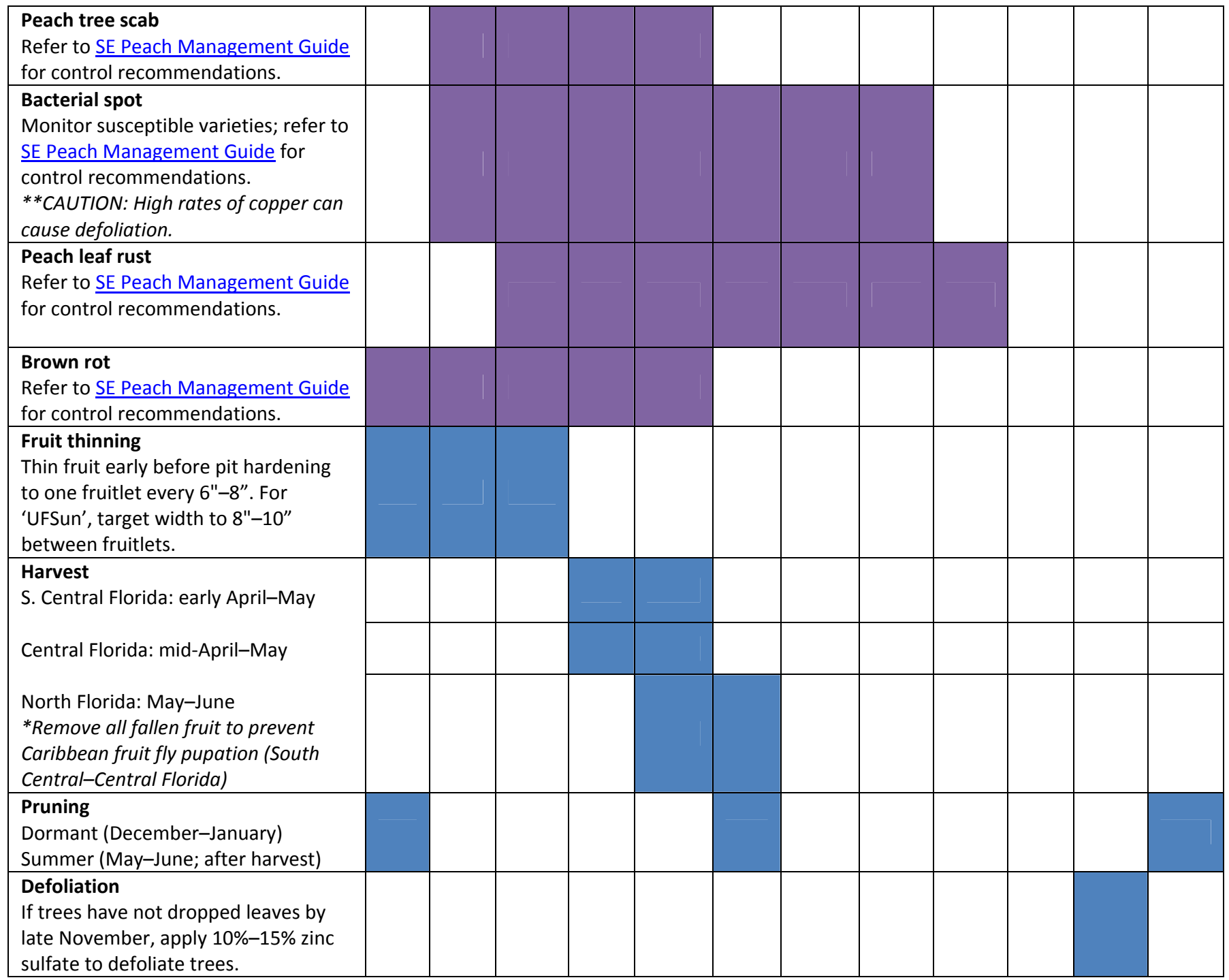

${ }^{z}$ Month during which various phenological stages occur varies depending on location (e.g., North Florida, Central Florida, or South Florida)

\begin{tabular}{|c|c|}
\hline Color & Activity type \\
\hline & Fertilizer management \\
\hline & Weed management \\
\hline Insect/pest management \\
\hline & Disease management \\
\hline & Cultural practices \\
\hline
\end{tabular}

